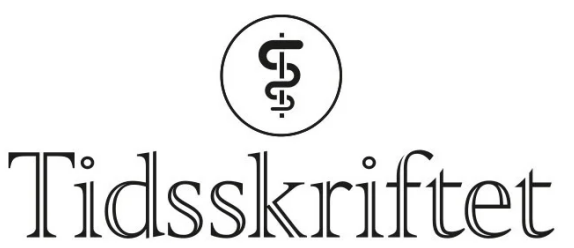

DEN NORSKE LEGEFORENING

\title{
Tiltak mot visceral leishmaniasis
}

\author{
VERDENS HELSE
}

KRISTOFFER BRODWALL

Email: kristoffer.brodwall@gmail.com

Ålesund sjukehus

\section{Insektsnett og endosebehandling med liposomal amfotericin B kan være nyttige tiltak mot visceral leishmaniasis.}

Visceral leishmaniasis antas å ramme 500 ooo mennesker årlig, hvorav 6o ooo dør. Sykdommen er særlig utbredt på det subindiske kontinent, der den også kalles kala-azar, som betyr «svart feber». Den skyldes parasitten Leishmania donovani som overføres ved bitt av sandfluer. Vektorkontroll er derfor en mulig tilnærming for å begrense smitte. I en studie har man sett på effekten av impregnerte insektsnett (1). Klynger i 12 geografiske regioner i India og Nepal ble randomisert til bruk av nett eller ikke. Ti husstander i hver region ble utstyrt med insektsfeller, og telling av antall fangede sandfluer ett år etter intervensjon viste en reduksjon på 24,9\% (95\% KI 1,8-42,5, p = o, 036) i intervensjonsregionene sammenliknet med kontrollene. Effekten er ikke like stor som det man har sett på reduksjon av antall mygg i kampanjer mot malaria ved bruk av myggnett i Afrika.

Standardbehandling for visceral leishmaniasis i India har vært amfotericin B deoxycholat, gitt som 15 doser (2 2 . Det er nå vist at én dose liposomal amfotericinB gir tilsvarende høy suksessrate (3). Tidligere studier har vist dårligere effekt av slik endosebehandling, men da har man brukt lavere dose enn $10 \mathrm{mg} / \mathrm{kg}$, som ble gitt i den ferske studien. Slik endosebehandling blir totalt sett billigere, til tross for at prisen for liposomal amfotericinB er høyere. Dessuten elimineres problemet med frafall under pågående behandling.

\section{LITTERATUR}

1. Picado A, Das ML, Kumar V et al. Effect of village-wide use of long-lasting insecticidal nets on visceral leishmaniasis vectors in India and Nepal: A cluster randomized trial. PLoS Negl Trop Dis 2010; 4: 5587 .

2. Holen $\emptyset$. Visceral leishmaniasis i Øst-Afrika. Tidsskr Nor Legeforen 2009; 129: 2265.

3. Sundar S, Chakravarty J, Agarwal D et al. Single-dose liposomal Amphotericin B for visceral leishmaniasis in India. N Engl J Med 2010;362: 504-12. 
Publisert: 6. mai 2010. Tidsskr Nor Legeforen. DOI:10.4045/tidsskr.10.0247

(C) Tidsskrift for Den norske legeforening 2023. Lastet ned fra tidsskriftet.no 26. april 2023. 